\title{
O DOIS E SEU MÚLTIPLO: REFLEXÕES SOBRE O PERSPECTIVISMO EM UMA COSMOLOGIA TUPI
}

Tânia Stolze Lima

A antropologia sustentou duas hipóteses aparentemente contraditórias a respeito dos selvagens: o animismo e o etnocentrismo. De um lado, os animais seriam dotados de características humanas e sociais; de outro, a humanidade cessaria nas fronteiras da tribo. Em um diálogo com estas hipóteses, este artigo é um estudo sobre um aspecto pouco ressaltado das cosmologias ameríndias, embora haja índices esparsos de sua difusão pan-americana: a noção de ponto de vista. Seu foco são alguns desenvolvimentos dessa noção relativos à caça de porco do mato, elaborados por um pequeno povo tupi, os Juruna (canoeiros, caçadores, agricultores, antigos habitantes das ilhas do baixo e médio Xingu, hoje vivendo em uma única aldeia localizada no alto curso do rio) ${ }^{1}$.

\section{O xamã vai à caça²}

— "Dukare! Venha nos dizer onde você viu porcos! Primeiro vá buscar a borduna. Tire o calção, pegue um punhado de cinzas e esfregue nos testículos. Então, segure a borduna e nos conte o que você viu". E os Juruna dão grandes risadas. É assim que Mareaji interpela seu primo que há pouco retornou da pesca dizendo ter visto em tal lugar uma vara de porcos. Trata-se de uma cena de "brincadeira" típica da relação entre primos cruzados, e quer dizer, nesse caso, mais ou menos o seguinte: eu o desafio a mostrar aqui diante de todos que você é homem! O sol se põe. Os homens vão-se reunindo à porta da casa da mãe de Mareaji, onde ele toma a palavra para interrogar Dukare, que se mostra muito envergonhado, e combinar com os outros uma caçada para o dia seguinte. Dukare é muito jovem, casado há pouco tempo, por isso tímido demais para assumir a organização da caçada. Mareaji o estimula a fazê-lo e ao mesmo tempo toma a frente do grupo. 
A caça de porcos é um tema que arrebata os Juruna tanto quanto o cauim, por isso, em um instante já não posso compreender o que os caçadores dizem. Todos falando ao mesmo tempo, gritos estridentes, onomatopéias de explosões de tiros, flechas silvando, porcos batendo os dentes, porcos em correria. Todos têm casos para contar e mímicas para fazer. Estão, talvez, encenando seu destemor. Essa caça é tida como uma empresa muito perigosa; os porcos são muito violentos e ousam afrontar o caçador, que só consegue escapar-lhes subindo em uma árvore, como aconteceu no passado recente com um finado. Nada porém dessa algazarra quando chegar o momento de matar. Se o caçador emite um grito, sua alma pode ir viver com os porcos. O mesmo destino pode ter aquele que se atemorizar diante dos porcos medonhos: assustada, sua alma foge e é capturada pelos porcos.

A caçada do dia seguinte, porém, foi uma decepção. "E os porcos?", indagou-se a Mareaji. "Dukare estava mentindo!" Não, ele não mentira, todos viram as pegadas. Mareaji ainda desfrutava de seu direito de fazer troça do primo.

Os Juruna sonham com a oportunidade de caçar porcos no rio. Quando vêem um bando atravessando, remam em sua direção e abatem-nos com borduna. Ocasionalmente, há que se mergulhar para pegar os que afundaram. É preciso ao menos dois tripulantes em cada canoa: um piloto e um matador. Não há caça mais lucrativa; rende em média de 15 a 20 cabeças, mais ou menos $500 \mathrm{~kg}$ de caça. O arrebatamento que os toma é tão grande que, se porventura os homens não estiverem presentes, as mulheres não perdem a caça. Armadas com pedaços de pau, mãos de pilão ou bordunas, conforme vi uma vez, as mais afoitas tomam as canoas e vão rapidamente matar os porcos, sob os gritos de forte emoção e contentamento das mais medrosas que permaneceram na aldeia. Encontrando-se uma porca grávida, pode-se enterrar o feto na aldeia, acreditandose que isto obriga os porcos a visitarem o lugar com freqüência, como os próprios Juruna fazem em relação aos lugares onde estão enterrados seus parentes.

Comparada com a de outros animais, a caça de porcos apresenta um simbolismo a mais: os Juruna situam-na no campo de ação do xamã. Quem estiver com desejo de comer dessa caça pode, diz-se, pedir ao xamã para atrair porcos.

Os porcos vivem em comunidades divididas em famílias e organizadas em torno de um chefe dotado de poder xamânico. Habitam aldeias subterrâneas e são produtores de cauim, o qual, na perspectiva humana, nada mais é que uma argila finíssima, conforme me contou uma mulher 
que sonhou com uma aldeia de porcos em cujo porto ela e eu tomávamos banho, até que descobrimos que estávamos atoladas em uma lama da qual os porcos diziam ser, justamente, sua mandioca puba.

O porco-xamã diferencia-se dos demais por carecer de pêlos no traseiro e ter pêlos avermelhados na cara. Representa um dos espíritos auxiliares que o xamã pode adquirir na iniciação. Em sonho, o xamã vê esse porco se transformar em um homem, e busca fazer amizade com ele, oferecendo-lhe o cigarro para fumar. Ao sentir que a amizade está consolidada, o xamã lhe diz que os homens de seu grupo pretendem fazer uma caçada; e o porco-xamã combina com ele o local e o dia da travessia. Os caçadores vão à caça.

É preciso deixar sobreviver o auxiliar do xamã, e isso vale, inclusive, para as caçadas que não são possibilitadas por xamanismo. Ninguém se preocupa em identificar antecipadamente o porco-xamã; ele sabe se livrar dos caçadores, atingindo a margem à frente da vara ou nadando com ligeireza rio abaixo. Em todo caso, ele é aquele que seguiu vivo adiante. Se o acompanham mais um ou dois, os caçadores também os deixam escapar: são a esposa e/ou o filho. No caso de alguém o matar sem querer, jogam-no no rio, pois a carne tem sabor de tabaco queimado em função do hábito de fumar o cigarro do xamã. Além disso, se alguém o matar, ele pode levar consigo a alma do xamã juruna que, conseqüentemente, adoecerá e morrerá.

A morte de um porco-xamã traz-lhe um destino singular. Sua alma vai viver com as almas dos mortos juruna, de cuja vida participa como um semelhante. Em contrapartida, um caçador que morresse na caça se tornaria um porco.

Conta-se que houve um tempo em que xamãs se especializavam no xamanismo de caça, consumindo um vegetal conhecido como "droga do porco" que cresce nos rochedos em cujo interior habitam os mortos. Desejando-se comer a caça, dizia-se ao xamã: "Vá chamar os porcos!" Ele usava para isso um apito de coco, réplica do apito que os porcos fabricam e definem como sua "flauta". Os porcos ouviam a música e diziam: "Eles vão dar uma festa! vamos! vamos!" Alegres com a oportunidade de dançar e beber com os Juruna, demoravam de um a três dias para chegar, conforme a distância em que se encontravam. Quando desembocavam no rio, atravessavam em direção aos Juruna, passando por entre as casas (situadas em uma ilha), e de novo entravam nas águas. "Nesse momento, vocês vão e matam, dizia o xamã. Era excelente!".

Havia um xamã que recebia na aldeia, durante a vigília, a visita de um porco-xamã, com quem ele fumava, bebia cauim e dançava. O visi- 
tante chegava acompanhado de todo o seu bando, e, é claro, somente o xamã podia vê-los. Quando lhe pediam para trazer porcos, ele convidava o porco-xamã para tomar cauim e acertar a caçada. Ao entrar em êxtase, o caçador interessado reapresentava-lhe o pedido: "Traga porcos para mim! Amanse-os para mim!". "Está bem!", consentia o xamã. Nessas ocasiões, o respeito ou comedimento no uso da linguagem condicionam o apaziguamento dos porcos. Mas, enquanto todos os caçadores sensatos exclamavam: "Minha presa estará mansa!", um homem apelidado Cabeça-de-Martim-Pescador descontrolou-se e disse: "Minha presa vai puxar meus testículos pendentes!". Lembraram-lhe que era preciso tomar cuidado, que não se brinca com a linguagem em um momento como esse, e, no dia seguinte, aconselharam-no a ficar em casa para evitar que os porcos o vissem. Ele era intrépido e não deu ouvidos. Ao fim da caçada, os companheiros encontraram-no semimorto, com os testículos arrancados e o corpo perfurado pelos dentes dos porcos enfurecidos. Mal teve força para contar-lhes como foi atacado. Sua alma partiu com os porcos sobreviventes em direção ao "rio Amazonas". Diversas varas de porcos juntaram-se a eles ao longo da viagem e Cabeça-de-Martim-Pescador mostrou-se um companheiro muito agradável, divertindo-os o tempo todo. Isso o xamã viu durante o sonho, e assim, conta-se, ele narrou:

Eles foram dando gargalhadas.

Os porcos são como os humanos,

Eles lhe pediram:

"Diga-nos os nomes das coisas!"

"O que é isto?"

"É isto."

Eles encontraram o mel-vagina.

"Que mel é este?"

"É o mel-vagina."

Eles encontraram o mel-andorinha.

"Que mel é este?"

"Este é o mel-pênis."

E os porcos gargalhavam.

"Ah, quer dizer que é melífero?"

"O pênis é melífero!"

E os porcos riam, ha' ha' ha'.

E ele partiu com os porcos dando gargalhadas.

Indagaram-lhe os nomes dos animais, dos méis... 
Ele recitou,

Eles davam gargalhadas,

"Ah, quer dizer que é melífero?"

Assim, quando o xamã está sonhando com porco,

Ou quando está embriagado,

Nós dizemos: "Não digam bobagens!".

Finalmente, os porcos elegeram Cabeça-de-Martim-Pescador como seu chefe ${ }^{3}$. Perante os Juruna, o infeliz atua como "intérprete" (para uma analogia juruna entre essa função e a função-esposa das mulheres, ver Lima 1986): ouvindo um caçador gritar seu nome, conduz o bando para fazer a travessia nas proximidades da aldeia.

Os porcos vêem a si mesmos como parte da humanidade e consideram a caça como um confronto em que tentam capturar estrangeiros. As brincadeiras feitas por um caçador em intenção dos porcos possibilitam a concretização de seu ponto de vista e desejo. Na ordem da realidade dos homens, os porcos atacam e matam o caçador, acontecimento que, aos porcos, parece uma simples captura, e, com efeito, o infeliz se torna um parceiro seu. Alimentando-se de cocos e minhocas, participando das danças e bebendo o cauim barrento, o caçador infeliz, com o passar do tempo, vai assumindo o aspecto do animal. Jamais, porém, se adapta completamente ao meio; na esperança de se curar dos ferimentos que adquire na mata e que infeccionam com a sujeira, vive se fazendo benzer pelo porco-xamã. Por fim é transformado em chefe da vara.

Assim, dotando os porcos de sensibilidade para divertir-se com a diversidade humana ou rir com as metáforas alheias, o mito aproxima a relação com os porcos daquela entre grupos humanos que falam línguas distintas (como o narrador mesmo adverte), marcando-a como relação de troca de brincadeiras, característica da conduta de primos cruzados (cunhados virtuais) e de estrangeiros que se tornam "amigos", ou afins potenciais. É justo porque a afinidade potencial é um aspecto virtual da relação com os porcos que o cuidado com a linguagem é necessário na caça para inibir a atualização da mesma ${ }^{4}$.

De tudo isso, os Juruna concluem que "os porcos se parecem com os mortos". De fato, ambos vivem em aldeias subterrâneas e são chefiados por afins potenciais (não por um parente); alegram-se com a possibilidade de tomar cauim com os Juruna e tentam capturá-los; um morto pode ir viver com os porcos e um porco pode ir viver com os mortos. Para culminar, assim como os mortos eram convidados até recentemente para beber cauim, os mitos afirmam que os porcos eram convidados para beber 
com os Juruna - a grande diferença é que não se tem de reprimir o riso diante dos mortos, muito pelo contrário.

No quadro do xamanismo e do ponto de vista dos porcos, os Juruna representam espíritos. O gesto (acima mencionado) em que o xamã dá seu cigarro ao porco que se transforma em humano para ele, tem um significado preciso: ele age como espírito auxiliar do porco, e, enquanto tal, inicia-o no xamanismo, da mesma forma que a iniciação de um Juruna no xamanismo dos mortos que habitam os rochedos depende de receber deles um cigarro para fumar. Ou seja, sob certo ângulo, os mortos estão para os Juruna assim como os Juruna estão para os porcos.

\section{O paradoxo do humano e do animal}

"Não temos crença; não explicamos nada". "Não cremos: temos medo!". Estas são palavras de um xamã esquimó a Knud Rasmussen (descendente de esquimó, com perfeito domínio da língua e habituado desde a infância à cultura do grupo), destacadas por Lévy-Bruhl como prova de uma clarividência excepcional. Recusando noções como crença e cosmologia, o próprio xamã recusaria a noção de animismo (Lévy-Bruhl 1931:XXXXII). Naturalmente, na aventura intelectual de Lévy-Bruhl não haveria lugar para uma noção, de seu ponto de vista, tão exemplarmente defeituosa: se afirmo que certos povos atribuem características humanas e sociais aos seres naturais, suponho uma distinção ontológica entre o homem e a natureza que pertence apenas ao meu pensamento; assim, perco toda chance de aproximação do sistema que quero compreender.

A noção de animismo, afirma ainda Lévy-Bruhl, é um meio tão cômodo de descrever e explicar certos fenômenos que mesmo os primitivos (cientes, muitas vezes, do que seus investigadores desejam ouvir) adotariam voluntariamente esse procedimento (Lévy-Bruhl 1931:80). De fato, os Juruna (para agradar ou não a mim e a si mesmos, ou, quem sabe, para encurtar a conversa) pareciam cair de bom grado e freqüentemente na tentação das racionalizações animistas. Por outro lado, uma proposição como "os Juruna pensam que os animais são humanos", além de destoar sensivelmente de seu estilo discursivo, é falsa, etnograficamente falando. Eles dizem que "para si mesmos, os animais são humanos". Eu poderia assim dizer que os Juruna pensam que os animais pensam que são humanos. É claro que o verbo pensar sofre um enorme deslizamento semântico quando se passa de um segmento da frase ao outro. O que para nós merece ser dito por soar absurdo, mas também estratégico para a descri- 
ção etnográfica, como um princípio que nos permitiria reconstituir a racionalidade alheia, para os Juruna é preciso ser dito (lembrado, considerado) por ser potencialmente grave, perigoso. O ponto é que os animais estão longe de serem humanos, mas o fato de se pensarem assim torna a vida humana muito perigosa.

Destituído de qualquer interesse teórico, desde o golpe de misericórdia que lhe foi aplicado por O Pensamento Selvagem, o animismo será aqui objeto de uma crítica etnográfica. O resultado a que chegaremos não constituirá novidade - a identificação sendo "condição solidária de todo pensamento e toda sociedade" (Lévi-Strauss 1976b:60); e a predação determinando "a ordem global da sociabilidade cósmica", da qual fazem parte as relações sociais no sentido estrito (Viveiros de Castro 1993:186). Mas os conteúdos etnográficos pelos quais passaremos são essenciais para a elucidação da relação humano-animal na cosmologia juruna e, portanto, para a determinação de alguns aspectos da noção de ponto de vista nessa cosmologia. Os Juruna nos permitirão, também, pôr a nu o paradoxo do animismo.

Em primeiro lugar, eles poderiam dizer-nos: o que vocês consideram como características humanas (definindo-as tanto natural quanto metafisicamente), não pertencem de direito ao ser humano. Temos de produzilas em nós mesmos, no corpo. Cada um, animal ou humano, pode produzir as características que melhor lhe agrade. Vejamos.

A lua nova é a ocasião em que a caça e o conjunto dos animais que habitam a floresta adestram seus filhotes. Os Juruna adestram suas crianças na lua crescente para evitar que seus ritos sejam simultâneos aos dos animais. A força física (para vencer na caça e na guerra) é o objetivo principal desses exercícios, mas também se valoriza o trabalho sobre forças de outro tipo, como a manducação, a expressividade verbal e a inteligência (na qual a função auditiva tem um papel essencial e que engloba a faculdade da crença). Em contraste com essas forças, todas dadas de uma forma incipiente, que aos humanos cabe desenvolver, apurar ou acentuar, situa-se, de um lado, a volição, muito intensa na infância, e que se procura moderar e tornar flexível; de outro, o instinto social (no sentido de inclinação para a comunicação com outrem). Representando, sem dúvida, a característica mais importante, o instinto social é constituído ao longo da formação do embrião por meio de uma intervenção ritual sobre a dieta de carne da futura mãe. O objetivo é impedir que sejam transmitidas ao feto uma conduta típica e complexa dos animais (peixes, inclusive), a saber, agressividade-e-medo, e uma conduta específica do tucunaré, o canibalismo. Segundo entendo, esse temperamento social que os Juruna 
buscam imprimir ao embrião não significa nada mais que ausência de agressividade-e-medo. Ele representa o grau mais baixo da força de defesa de que é capaz um ser vivo. Sua imagem ideal é, de um lado, aquela mansidão (um misto de confiança e tranqüilidade) que os mais diversos filhotes e o bebê (bem alimentado) demonstram diante dos humanos, e, de outro, a gratificação que a simples observação dessa mansidão desperta. Em uma palavra, ser sociável é não estar amedrontado-e-violento.

Esta análise abreviada sobre as características sociais e humanas de que fala a hipótese animista permite-nos apreender alguns aspectos fundamentais da cosmologia juruna. A reprodução humana e a socialização são baseadas em intervenções que neutralizam um afeto animal (agressividade-e-medo), freiam a volição, e capturam capacidades e forças animais (como a audição excepcional do japim, a dentição do macaco, a resistência do tatu) ou vegetais (o som produzido pela taquara).

Passemos a outro aspecto, relacionado com a noção de alma. Passemos precisamente ao que podemos aprender sobre a mesma a partir do animal, deixando de lado, por não nos interessar diretamente aqui, as dimensões relacionadas com o tema da morte. O animal, segundo fragmentos etnográficos dos mais variados tipos, é fonte para uma apreensão sintética da noção de alma, enquanto princípio pessoal. Tomada por esse ângulo, a noção remete ao pensamento reflexivo e à consciência de si como aquela de um eu humano, dotado, enquanto tal, de relações sociais, condutas culturais e capacidade para distinguir humano e animal. Reconhecendo-se como pessoas, os animais (bem como os humanos e os espíritos) têm um sentimento ambíguo para com os Outros (imama, que significa a relação de alteridade nos mais diferentes campos: parentesco, localidade, língua e cultura): desejam aproximar-se e fazer amizade; mas sentem medo.

O sonho é o plano privilegiado da comunicação entre os humanos propriamente ditos e as mais diferentes espécies animais (e outras categorias ontológicas, como os ogros e os espíritos). Aí, o animal não apenas se toma por, mas, sob certas condições, se transforma em humano para alguém; é identificado como pessoa por outra pessoa, e os dois travam (ou não) uma aliança mais ou menos durável (isto é, que pode ser experimentada em diferentes noites de sonho).

Não quero encerrar-me em um paradoxo, argumentando que os Juruna não confundem o humano e o animal visto que atribuem aos animais a capacidade de não fazer essa confusão. O animismo parece, de fato, colocar um paradoxo do mesmo tipo daquele que Lévi-Strauss (1976a:334-335) batizou de paradoxo do relativismo cultural (advertindo 
já a existência de variedades). É esse o retrato paradoxal do animal: ele faz a distinção humano/animal e não se apercebe que é animal. Com efeito, (ser) animal é uma condição que não pode ser concebida na primeira pessoa; ele é uma forma da consciência de outrem, ao passo que a consciência de si envia diretamente ao humano.

Atingimos assim duas conclusões. Que a relação entre o humano e o animal é marcada por uma contradição entre o mesmo e o outro: a alteridade real do animal remete ao mesmo tempo à sua identidade virtual. $\mathrm{E}$ que existe uma dicotomia muito clara entre as disposições enraizadas no corpo e os atributos da alma. Se o humano captura as primeiras dos animais, ele lhes empresta, pareceria, a cultura (linguagem, interesse pelo Outro, distinção humano/animal e formas de interpretação da realidade). Não podemos, porém, desconsiderar que, ao postularem que tudo o que existe tem uma alma, os Juruna também postulam que os atributos culturais são atributos da alma.

Esses fatos evocam diretamente a noção de "reciprocidade de perspectivas" ("o homem e o mundo se espelham um no outro") com que Lévi-Strauss argumenta em favor da superação da velha dicotomia entre religião e magia (antropomorfismo da natureza versus fisiomorfismo do homem), sustentando (por intermédio de uma estranha comparação entre motoristas no trânsito e a inserção do homem em um mundo de signos) que o homem se defronta com o mundo, tomando a ambos e no mesmo golpe como sujeitos e objetos (Lévi-Strauss 1976b:254-256). É nesse contexto teórico que eu situaria a noção de ponto de vista.

\section{O um e seu outro}

Essa noção coloca questões que a análise baseada em tropos, além de não resolver - como argumentou Turner (1991), a propósito da análise de rituais Jê e Bororo) —, impede de localizar. Noções como metáfora e metonímia (ou congêneres, como totemismo e animismo, na conceituação proposta por Descola ${ }^{5}$ ) nos atrapalham em nosso anseio de determinar a lógica subjacente das chamadas proposições aparentemente irracionais.

Entre outras proposições desse tipo, a etnografia juruna apresenta esta: do ponto de vista dos mortos, tucunaré é cadáver. Se o tucunaré é um dos peixes mais importantes da dieta dos Juruna, segue-se que eles são canibais!... Contudo, em lugar de tomar a equação como uma variante de "os Bororo crêem que são araras", existe, parece-me, outro caminho, pois, se o problema se resumisse a um caso de metáfora, os Juruna 
diriam na primeira pessoa que o tucunaré é carne humana e não o incluiriam em sua dieta (como fazem, aliás, com um tipo de saúva, cujo sabor é dito semelhante ao da carne de Índio). O fenômeno cuja presença quero assinalar não é um tropo, mas a atribuição a outrem de um juízo sobre si. Mais, portanto, que traçar as relações simbólicas entre termos como tucunaré e cadáver, o que proponho é a busca de um conceito por meio do qual possamos explorar as condições culturais (e não simplesmente lógicas) da verossimilhança de equações como essas. Em poucas palavras, a questão para a qual quero chamar a atenção é que mundo é este em que metáforas desse tipo são operativas. Mundo no qual os tropos representariam apenas, como argumentam Deleuze e Guattari (1995:13), "efeitos que só pertencem à linguagem quando supõem o discurso indireto" .

Em meu trabalho de campo, uma das primeiras coisas a chamar-me a atenção foi a marca indelével, mas muito misteriosa, da noção de ponto de vista. Certas frases, ditas para mim em português, como "isso é bonito para mim", "bicho virou onça para ele", "apareceu caça para nós quando estávamos fazendo a canoa", pareciam remeter exclusivamente à estrutura gramatical de uma língua que eu não dominava, mas que transparecia no português dos Juruna. Depois que comecei a arranhar algumas frases, as construções que ensejavam tais traduções nunca deixaram de soar estranhas; dentre as práticas juruna mais difíceis de assimilar eu as destacaria, em primeiro lugar e sem hesitação. Amãna ube wï- não é fácil dizer isso sem se desconcertar, desagradavelmente ou não. Sentiame dizendo "choveu para mim", e não "choveu onde eu estava". Essa maneira de relacionar à pessoa até mesmo os acontecimentos mais independentes e alheios à nossa presença deixa sua marca na cosmologia juruna, mas nem presumo que todas as categorias gramaticais tenham o mesmo papel em uma cultura ${ }^{6}$, nem acredito que exista a mais remota possibilidade de algum de nós se colocar na pele de um Juruna para captar o sentido que assumiria a vida humana em uma situação em que, para nós, de repente, se tornaria aceitável, ou mesmo perfeitamente justo, dizer: Chove para mim. Esse sentido diria respeito no máximo a uma virtualidade que está em nós, virando-nos pelo avesso. Qualquer dragão sutil, como escreveu Lawrence (1986), nos aferroa no meio da plenitude, dada essa grande máquina em que consiste o cosmos onde vivemos, e morremos de tédio.

Eu gostaria, pois, de assinalar que o único "ponto de vista do nativo" que podemos e desejamos alcançar nada tem a ver com uma identificação imaginária, conforme Geertz (1983) argumentou de forma contundente. 
O princípio ego-sócio ou etnocentrado por meio do qual os Juruna organizam sua experiência é o correlato de um princípio à primeira vista semelhante ao relativismo, tal como o concebe nosso senso comum (antropológico ou mais amplo). Assim, para si mesmos, os porcos tocam flautas, que para os humanos são simplesmente os cocos (esvaziados do miolo, comida desse animal) que os porcos fuçam, provocando a emissão de um som que lembra o apito para uma audição humana, mas cuja musicalidade, na audição dos porcos, é tão rica como aquela das flautas.

A hipótese é, pois, que não são realmente dois princípios distintos e independentes, mas um só e mesmo dispositivo conceitual — justamente a noção de ponto de vista. Dependendo apenas do tema em foco, é que ele ora nos lembra o-centrismo, que normalmente se atribui aos índios (mais ainda do que a nós), ora o relativismo, com o qual contudo, desde que assinalado entre os índios, não sabemos bem o que fazer.

O ponto de vista implica uma certa concepção, segundo a qual só existe mundo para alguém. Mais precisamente, seja um ser ou um acontecimento - e as evidências que minha análise permitirá destacar apontam para a não pertinência dessa distinção entre substância e acontecimento na cosmologia juruna (Lévinas 1957; Viveiros de Castro 1996b) —, o que existe, existe para alguém. Não há realidade independentemente de um sujeito. No entanto, conforme tentarei mostrar nas seções seguintes, sucede que o que existe para o caçador quando ele toma a palavra para falar de si mesmo é apenas parte daquilo que existe para outrem.

Argumentei em outro trabalho (Lima 1995:425-438) contra a possibilidade de interpretar o que então chamei de relativismo juruna como uma versão do relativismo cultural. Baseava-me na estreita dependência do relativismo cultural com uma noção de natureza, em sua indiscutível aliança com o universalismo, ou seu compromisso indissolúvel com a oposição sujeito/objeto ${ }^{7}$. E mostrei como os materiais juruna conspiravam em favor de uma teoria muito diferente.

Quero esclarecer, contudo, que não pretendo negar que o perspectivismo indígena possa ser considerado como uma variante do relativismo, pois, afinal, nada diz que não possa haver outras formas de pensar o relativismo muito diferentes daquelas concebidas pelo pensamento ocidental. Não haveria de ser pela vertigem que sentimos em uma província do pensamento humano onde Protágoras não encontra o seu Platão, nem Demócrito ou Sexto Empírico que nos negaríamos a perceber a presença do relativismo. O que sustento é que se trata de uma concepção da alteridade e da verdade tão peculiar que a comparação com o relativismo cultural é uma ferramenta bastante útil para apreender sua especificidade. 
Posso agora aprofundar minha perspectiva a partir de uma releitura de trabalhos de Viveiros de Castro (1986; 1996a), onde o tema da Palavra Alheia (e do discurso citado) - em que consistem as canções dos mortos e do inimigo, entre os Araweté - é analisado segundo uma perspectiva que me permite ampliar a minha, fazendo alguns ajustes importantes. E também a partir de uma leitura das interpretações que Signe Howell (1984) e Kaj Århem (1993) propõem, respectivamente, para um grupo da península malásia, os Chewong, e um grupo amazônico, os Makuna (Tukano), cujos materiais apresentam paralelos com os meus.

Entretanto, eu não poderia fazer aqui uma exposição da complexa análise sobre o canto do matador - cuja palavra se entrelaça com a da vítima - e o canto xamanístico - ele mesmo "a área mais complexa da cultura Araweté" (Viveiros de Castro 1986:542)8. Nem uma exposição dos ricos materiais chewong e makuna. As interpretações de Howell e Århem, apesar do cuidado e esforço de ambos para não caracterizar seus materiais como relativismo, desembocam neste direta ou indiretamente, revelando uma polarização entre o relativo e o absoluto. Entre os Chewong, todos os seres são dotados de consciência, e cada espécie natural (bem como as diferentes categorias de espírito) possui um tipo particular de olho. Em um exemplo prosaico, para o cachorro que se entrega a comer as fezes de uma criança parece que ele está comendo uma banana; assim, seu gesto só é deplorável ao olhar humano; do seu ponto de vista, representa uma conduta perfeitamente razoável (Howell 1984:161). Em resumo, o olho estaria para as diferentes categorias ontológicas como a cultura para a humanidade: não se pode julgar a conduta do outro, visto que a percepção que ele tem do mundo é determinada por seu olho e sua conduta é perfeitamente correta.

Entre os Makuna, os humanos e os animais possuem uma essência espiritual comum. Os segundos transformam-se em animais a fim de circular no mundo dos humanos, e transformam-se em humanos quando retornam às suas próprias moradas. Os urubus, por exemplo, que, segundo as aparências, comem cadáver, vêem o cadáver como um rio muito piscoso, conforme assinalam os vermes que nele pululam. Inversamente, certas regiões do rio são tidas como pertencentes aos urubus, e os humanos ali não devem pescar porque o que lhes parece peixe na verdade são vermes (Århem 1993:116).

A interpretação de Kaj Århem está baseada na hipótese de uma humanidade essencial, ou uma unidade metafísica de todos os seres, e na oposição conceitual entre essa essência e a aparência. Também Howell (1984:157, 159, passim) invoca uma "verdadeira essência das coisas", e o 
próprio título que ela dá ao capítulo onde desenvolve o tema é revelador: "relatividade na percepção". Ambas as interpretações são, sem dúvida, bastante coerentes com os materiais etnográficos, mas, como se sabe, no que diz respeito a fenômenos dotados de generalidade, a perspectiva etnográfica mostra-se demasiado estreita. Meus materiais não são menos estreitos, e torço para que um estudo comparativo sobre o perspectivismo nas cosmologias indígenas seja empreendido ${ }^{9}$. A ressalva não me impediria de dizer que a conclusão elaborada por Århem e Howell parece-me um pouco apressada. Pois vejamos.

O xamã, capaz de ver o mundo tal qual ele é, capaz de descobrir e revelar a natureza última das coisas, teria um ponto de vista descentrado (Århem 1993:124). Nem a noção de descentramento nem a de natureza última das coisas (Howell 1984:157, 159, passim) são muito apropriadas, a meu ver. O xamã é tão solidário quanto qualquer outro (humano, animal ou espírito) com o seu sistema de referências. Com essa fórmula relativista, minha intenção não é apontar o óbvio; desejo ressaltar que a própria inserção do xamã nesse mundo marcado pela variação dos pontos de vista é determinada por sua solidariedade (no duplo sentido do termo, e positiva ou negativa) com o sistema de referências humano. Ressalto que a noção de descentramento jamais explicaria por que, na "ecosofia 'xamânica'" makuna, apenas certas regiões do rio, pertencentes aos urubus, são habitadas por peixes que os urubus não comem, por serem vermes para os próprios urubus; peixes que por isso os humanos não devem comer. Tampouco explicaria por que apenas em certos períodos os Juruna que comessem tucunaré teriam de tomar (outra dose de) emético para vomitar (de novo) o cheiro do cadáver do parente morto. Em ambos os casos - certas regiões de pesca ou certos períodos da vida (o luto) - vigora o ponto de vista alheio, do qual o xamã não é mais que o porta-voz. Ou o "rádio", como dizem os Araweté, onde cantam as palavras alheias (Viveiros de Castro 1986:543). Permanece assim verdadeiro que, ainda que ele não se situe no ponto de vista de Sírio, ainda que sua função não se baseie em descentramento algum, Howell e Århem têm razão ao assinalar que seu ponto de vista é privilegiado. E o é justamente por ser ele o ponto de vista da variação entre aqueles pertencentes às diferentes categorias de alteridade. Além disso, ao menos entre os Juruna, que perderam os xamãs e relutam em assumir esta função, o ponto de vista da variação é a própria sabedoria; e esta é humana (Lima 1995: 438).

Também minha primeira interpretação apresenta um enfoque que merece ajuste. Em estudos dedicados ao que chamou de metafísica guarani, Pierre Clastres (1974a; 1974b) ressaltou que não é porque o pensa- 
mento guarani recusa o um que devemos concluir sua opção pelo múltiplo - esta oposição sendo demasiadamente grega. Nem o um nem o múltiplo, trata-se antes de uma afirmação do dois. A verdade na cosmologia juruna (onde, aliás, inúmeros paralelos podem ser traçados com a cosmologia guarani), sendo decididamente alheia ao um, alheia ao ponto de vista de Sírio, foi por mim interpretada como pluralidade e polivocidade - projetada, como ela é, sobre planos cósmicos diferenciados ou dispersa entre pontos de vista diferentes (Lima 1995:438). Porém, isso é apenas uma abordagem de conjunto sobre o perspectivismo juruna, e não deve ser compreendido como multiplicidade na acepção da metafísica ocidental. Em uma abordagem mais localizada ou atenciosa para com o regime da variação dos pontos de vista o que se observa é um regime binário: tucunaré/cadáver, carniça/moqueado, água/sangue, puba seca/carne humana podre, humanos/porcos e assim por diante. Estas categorias sendo objeto de uma disputa entre os humanos e alguma outra categoria de alteridade.

Não creio afastar-me da hipótese de Clastres no que vou tentar mostrar agora: como o dois também tem o seu múltiplo. Passamos assim para a análise da etnografia da caça dos porcos apresentada no início deste artigo.

\section{A palavra está com o animal}

A alma animal - merecendo ser distinguida da alma humana - tem como um de seus aspectos o fato de que, ao tomar-se como humanos, os porcos são dotados de certas práticas que se reportam à cultura juruna ${ }^{10}$ : cauim, xamanismo, grupos baseados no parentesco, guerra, atitudes de brincadeira entre os afins, música de sopro etc. Não me cansaria de frisar que essa unidade não está, absolutamente, a serviço de uma identificação com o animal, mas, muito pelo contrário, de uma variação entre os pontos de vista humano e animal, a saber, uma variação entre a caça e a guerra, que, ela sim, é plena de importância. A noção de ponto de vista atuando aqui como articulador da alteridade real e da identidade virtual dos porcos relativamente aos humanos.

Diríamos que aquilo que os humanos apreendem como caça, os porcos apreendem como guerra. Entretanto, esta é uma formulação equivocada, pois pressupõe um único e mesmo acontecimento, visto por dois tipos tão diferentes que a apreensão de um só pode ser irredutível à do outro. A caça dos porcos não põe em cena uma mesma realidade vista 
por dois sujeitos, conforme nosso modelo relativista. Pelo contrário, ela põe um acontecimento para os humanos e um acontecimento para os porcos. Em outras palavras, ela se desdobra em dois acontecimentos paralelos (melhor dizendo, paralelísticos ${ }^{11}$ ),

humanos caçam porcos

humanos são atacados por inimigos

que são também correlativos, e que não remetem a nenhuma realidade objetiva ou externa, equiparável ao que entendemos por natureza. Um é o referente do outro. Diremos, pois, que a caça apresenta duas dimensões, dadas como dois acontecimentos simultâneos que se refletem um no outro.

A duplicidade é a lei de todo ser e de todo acontecimento. Seja a experiência humana. Jamais apresenta uma única dimensão; ela é dupla, por definição. Uma é a da realidade sensível, na qual o tucunaré e o cadáver, os porcos e os humanos (e assim por diante) são distintos; a outra é a da alma. Esta última se desenvolve no sonho e nela atuam regras que não são necessariamente as mesmas que vigoram na realidade sensível. Ou melhor, o ponto de vista do Outro pode ali se impor enquanto verdade para os humanos. Desse modo, na apreensão da alma (dada em suas experiências oníricas), um bando de porcos correndo em disparada na floresta corresponde a outra coisa para o caçador, a saber, um ou mais inimigos.

Nesse contexto, a experiência da alma humana, diferentemente daquela da alma animal, não consiste em consciência de si como sujeito. De um lado, enquanto princípio vital situado no coração, a alma é uma parte do eu e não pode explicar por que o eu é uma pessoa ${ }^{12}$; de outro, ela é o duplo do sujeito, e escapa, enquanto tal, ao mesmo. Sua experiência não é, então, a subjetividade, exceto que alguns fragmentos seus podem vir a preencher a consciência. Assim a perda da alma, por captura efetuada pelos porcos em uma caçada (ou pelos mortos em outras circunstâncias): o caçador não tem a vivência disso, ele não pode ter — no limite porque ainda não está morto. Ele emagrece, definha, torna-se profundamente melancólico; o xamã pode contar-lhe a aventura que sua alma vive ao longe, e se não tem sucesso em trazê-la de volta, o caçador morre. O sonho, por sua vez, pode proporcionar um conhecimento parcial da vida da alma. O próprio caçador pode se lembrar de fragmentos da história não lembrada da vida de sua alma junto aos porcos.

A experiência do animal também tem duas dimensões. Já conhecemos a dimensão sensível da experiência dos porcos, na qual eles se vêem 
como pessoas e agem como humanos: bebem seu cauim, tocam sua flauta, defrontam-se com desconhecidos na mata, no rio ou nas margens das roças alheias.

Se esse jogo de simetrias que a cosmologia juruna constrói nos dá algum direito de seguir, podemos deduzir que a dimensão "animal" do animal (a face animal dos porcos), fazendo parte da experiência sensível dos humanos, e escapando inteiramente aos porcos, sendo a parte de si ignorada pelo sujeito, está para os porcos assim como a experiência da alma está para os humanos. Se o animal pudesse ver a si mesmo, ele se defrontaria com seu duplo. Ora, isso é tão impossível quanto o é para um humano se defrontar com sua própria alma. O sujeito e seu duplo se ignoram.

O duplo é invisível não exatamente porque seja imaterial, ou mesmo porque tenha uma matéria diferente da do corpo. Alma e corpo são conceitos que não designam primeiramente substâncias, mas efeitos de perspectivas. Esses conceitos operam por intermédio de uma noção, o ponto de vista, que articula tanto as duas dimensões da experiência humana (se minha alma viu porcos vivos, eu verei inimigos) quanto a dimensão sensível de um com a dimensão espiritual do outro. Poderíamos designar as duas últimas como Natureza e Sobrenatureza, não esquecendo que tais conceitos são necessariamente dependentes do ponto de vista de alguém, isto é, funcionam como categorias relacionais.

Antes de prosseguir, gostaria de fornecer uma evidência suplementar para a interpretação que proponho. Tomemos o tema da captura da alma do caçador pela caça. Um aspecto "aparentemente irracional" desta... como dizer... metafísica da caça seria o seguinte. Porcos e humanos confrontando-se na caça são viventes - suponhamos. Uma premissa cosmológica elementar diz que é a alma de um vivente que assinala a presença do mesmo às almas (dos mortos ou ogros-fantasma). Ou seja, assim como um vivente não pode ver (o corpo de) uma alma, uma alma só pode ver e atuar sobre a alma do vivente. Na caçada, porém, a alma do caçador, se lhe ocorre abandonar seu sítio devido ao medo que atinge o sujeito, não apenas é visível para os porcos como é capturada e vai viver com eles, ganhando, com o tempo, corpo de porco, visível ao olhar humano. Minha interpretação é, pois, perfeitamente justificada: uma vez projetada como duplo, a alma dos caçadores faz parte da apreensão sensível dos porcos, em contraposição ao fato de que aquilo que para os porcos representa seu próprio duplo faz parte do campo da apreensão sensível humana. O que, portanto, é Natureza para os humanos intercepta a Sobrenatureza para os porcos, e vice-versa. É por isso que estas são categorias que antes de distinguirem este mundo e o além em termos absolutos dife- 
renciam planos que compõem cada ser e acontecimento. São elas que definem a unidade e a relatividade do dois.

Voltemos aos dois acontecimentos paralelos em que consiste a caça. Cada sujeito - caçadores e guerreiros - tem o seu próprio ponto de vista como "realidade sensível", e considera o ponto de vista do Outro como a dimensão supra-sensível ou "sobrenatural" da sua experiência (não haveria de ser à toa que os porcos têm o seu xamã!). Deste modo, o acontecimento, que para cada sujeito é o único verdadeiro, é considerado por ele de um duplo ponto de vista, o seu próprio e o do Outro. Ou seja, tanto a caça quanto o caçador apreendem o "seu" acontecimento de um duplo ponto de vista:

os caçadores perseguem uma caça que se concebe como guerreiros os guerreiros se defrontam com afins potenciais que agem como inimigos

Sendo que o ponto de vista do Outro incorporado pelo sujeito representa uma virtualidade, que pode se atualizar ou não em função da ação efetuada por cada um.

Assim, o acontecimento que existe para os porcos deve ser (em uma formulação a nosso ver grosseira, mas, na verdade, bem adequada ao espírito dos Juruna) reduzido a uma mentira pelos humanos. Na mesma medida em que os caçadores querem impor o seu ponto de vista aos porcos, estes não perderiam a chance de fazer o mesmo. Não se entregariam ao inimigo sem luta. Os caçadores, de sua parte, tampouco podem ignorar as disposições da caça. Uma luta entre caçadores e guerreiros está em curso.

Podemos aqui abrir parênteses para constatar que colocar o problema em termos relativistas e invocar em seguida alguma "verdade última" equivale a não perceber a natureza do problema. Aproveito para lembrar também, mais uma vez, que é totalmente descabido buscar qualquer identificação imaginária com o caçador. Colocarmo-nos em seu lugar só nos levaria, ironicamente, a assumir o ponto de vista dos porcos. Caberia observar, ainda, que podemos perspectivar a resistência que os antropólogos "culturalistas" impomos à leitura ecologista da guerra indígena como caça. De fato ela não é caça, nem que seja porque a própria caça não o é. Mas isso não significa absolutamente que os caçadores só praticam a guerra - esta ainda é uma interpretação imaginária. O que nos dizem os fatos diante dos quais nos encontramos é que caçadores combatem guerreiros. A caça incorpora a guerra (assim como o caçador deve incorporar o ponto de vista dos porcos), mas não deve se confundir com ela. Sendo assim, a tentativa de interpretar a relação com os animais 
como projeção das relações humanas defronta-se com uma perda etnográfica substantiva. A distinção humano/animal é plena de importância para um pensamento sempre pronto a também levar em conta a animalidade específica do animal que atua como Outro.

Uma luta então está em curso - luta entre a caça de um e a guerra do outro. O infortúnio do caçador é o resvalamento da caçada na guerra. Cientes da dimensão sobrenatural que o ponto de vista dos porcos representa para eles, os humanos utilizam-se de meios através dos quais pretendem impedir toda possibilidade de os porcos virem a impor seu ponto de vista.

Na preparação da caçada, não se brinca com as palavras à custa dos porcos, não se pode bancar o primo cruzado ou amigo do animal. Na caçada, não se exprime o medo gritando, como se o caçador fosse a presa. Se, para os porcos, os humanos são seus afins potenciais, e se a caça é uma guerra, aquele caçador que aceitar este ponto de vista favorece a atualização da intenção virtual da caça: os porcos (o atacam e) o capturam, e ele, morto para os humanos, acabará transformado em porco.

Como é peculiar ao diálogo da afinidade (onde se aguarda o momento certo, mas não se deixa o humor irônico sem resposta, isto é, onde o "estímulo" e a "resposta" são constitutivamente separados por um intervalo de tempo maior que o diálogo comum), dirigir brincadeiras aos porcos é ceder-lhes a palavra involuntariamente, precipitando assim uma inversão que se faria sentir em ambos os acontecimentos paralelos:

os porcos matam humanos

os guerreiros assumem o ataque e capturam afins potenciais

Ao animal não pode ser dada nenhuma chance de tomar a Palavra. É esta também a mensagem do mito de Cabeça-de-Martim-Pescador, bem como dos relatos que associam a caça dos porcos à intervenção do xamã. Se a palavra do xamã encerrasse uma moral, ela seria formulada assim: cuidado! os porcos se parecem conosco; portanto, não os tratem como pessoas; senão vocês viram porcos.

Ao fim da caça, a alma da presa segue com seu predador ${ }^{13}$. Ele abordará sua relação com a presa de duas perspectivas distintas. Dirá "meu porco" (u-me-huða), empregando uma categoria de posse segundo a qual o objeto possuído é de direito (e de fato) alienável. Dirá "minha presa" (u-mita), para exprimir que ela é uma parte inerente de si mesmo, o caçador. Partilhada em refeições coletivas, a carne, sob a forma de alma parcial (dente, pêlo, fragmento de osso), poderá acarretar infelicidades para 
o caçador: morder, espetar, furar o interior do corpo de seus filhos pequenos. Mas isso nos levaria a uma outra dimensão da cosmologia juruna que aqui não podemos analisar.

\section{O dois e seu múltiplo}

Para alinhavar algumas conclusões, gostaria de destacar alguns fios soltos. (1) A palavra do caçador, desencadeadora de um diálogo fatal com os porcos, assumiria aqui um papel que lembra a operação sacrificial: ela traça - "por antecipação, e como que em pontilhado" (Lévi-Strauss 1976b: 259-260) — uma continuidade irreversível entre o caçador e a caça. Reservemos as figuras da antecipação e da linha pontilhada, sem com isso preservar a figura do sacrifício. (2) O fragmento onírico porcos abatidos, índice de que a alma caçou porcos, significa que porcos surgirão no caminho do caçador; o fragmento porcos correndo, índice de que inimigos perseguiram a alma, significa que surgirão inimigos para o caçador. (3) Todo ser ou fenômeno é dois: os caçadores, os porcos, a caçada. (4) A noção de alma humana não remete à experiência subjetiva — este é o último fio, que articularei com os anteriores a fim de mostrar que a caça desenha uma forma pura do tempo: um tempo bilinear múltiplo.

A caça aqui e agora - constituída como dois acontecimentos paralelos que se refletem um no outro e que compreendem, cada um, duas dimensões paralelas que se refletem uma na outra - pode ter sido sonhada por um dos caçadores. Ela é, nesse caso, um acontecimento paralelo a outro transcorrido em outro momento e lugar. Ou seja, a caça-e-seu-outro tem ela mesma seu outro, deslocado no tempo e no espaço. Tempo e espaço obedecem, assim, ao mesmo princípio de paralelismo, colocando um problema particular e mais complexo - o tempo, particularmente, já que se permite desconhecer a simultaneidade.

Devido às experiências agradáveis que o caçador vivencia, a alma vai procurar, enquanto ele dorme, aventuras em terra alheia, onde muitas vezes o que vigora é o ponto de vista, a palavra ou a verdade do Outro. Na manhã seguinte, se o caçador se lembra de porcos abatidos, ele fica à espera do que talvez esteja se armando para ele. O sonho tanto pode significar uma caçada que a alma prosseguiu fazendo em função de alguma outra ocorrida em sua experiência sensível nos últimos dias, como significar uma caçada que foi iniciada pela alma e está para se realizar, para ele, nos próximos dias. O duplo da caça pode assim ser ou o prolongamento de um passado ou o desencadeamento de um futuro. 
Se a alma vê um bando de porcos correndo livremente, o caçador teme ser atacado por inimigos. Ele nada faz durante os próximos dois ou três dias, não vai à floresta nem navegar. Tampouco narra o sonho. Mas será que nesse sistema o medo do caçador tem uma conotação específica? Sim, específica e positiva. Em lugar de se encolher de medo por causa daqueles que estão indo em sua direção, ele suspende suas atividades fora da aldeia para ficar tranqüilo. Seu medo é prudência. Também é muito mais que isso. Não é que o inimigo vá passar e ele não deva estar lá por isso; não é que em tal lugar da floresta passará um inimigo e o caçador corra o risco de passar pelo mesmo lugar, na mesma hora, e depararse com ele. É uma maneira bem diferente de conceber o tempo, maneira que não se diz nem como acaso nem como necessidade. O sonho não é um espelho onde o caçador veria o seu futuro, mas uma linha paralela de tempo onde a alma do caçador se engaja em um acontecimento novo. Não há nem encontros acidentais, nem encontros determinados pelo destino. O caçador paralisa-se porque não estando ele lá, o inimigo não passará. Seu medo, além de prudência, por meio da suspensão das atividades que definem a linha temporal do caçador, é uma imobilização do tempo outro, ruptura do acontecimento que se desenha ao longe para ele. $\mathrm{O}$ caçador recusa-se a refletir a imagem do acontecimento que, longe, começou a se desenhar contra ele.

Se todo acontecimento depende de seu duplo para se completar como tal, e se o caçador, por meio de sua ação-e-palavra, pode ou não se oferecer como espelho para a duplicação do acontecimento em sua experiência sensível, cabe ainda determinar com mais exatidão como o um se articula com seu outro.

Quando se trata de perspectivismo, conforme ressalta Deleuze em seu estudo sobre Leibniz e o pensamento barroco, e cujo conceito de "dobra" não deixa de evocar o perspectivismo paralelístico que estamos estudando, nada de sujeito e objeto definidos previamente: "será sujeito aquele que vier ao ponto de vista, ou sobretudo aquele que se instalar no ponto de vista" (Deleuze 1991:36).

Também a caça aqui e agora, parada das duas linhas espaço-temporais, é momento em que a apropriação da Palavra é tudo. Pois é essa apropriação que responderá por uma inflexão a ser desencadeada em qualquer uma das duas linhas. Quem se precipitará sobre a linha sobrenatural do outro, o caçador ou o guerreiro? A caça (a um só tempo virtual e real) é quando o humano inicia e sustenta a inflexão; ela é a apropriação e a afirmação do ponto de vista do homem pelo homem. A guerra (simples virtualidade, e que pode se exprimir como acidente com, ou mesmo 
a morte de um caçador inexperiente) é a apropriação do ponto de vista pelos porcos. O infortúnio do caçador é o resvalamento da sua caça na guerra do outro, assim como o infortúnio do animal é o resvalamento de sua guerra na caça.

Na vida do caçador, nem mesmo a palavra é representação. Tomada em seu ângulo performativo, destinada, durante a combinação da caçada, a passar de um ao outro, circular entre todos e não se imobilizar em ninguém, e aliada a todo tipo de linguagem (gesticulação, estampido, grito e silvo de flecha), a palavra é caça, antecipando ou pontilhando seu duplo. É por seu intermédio que o antes e o depois são constrangidos a se quebrar em dois, emparelhar-se e refletir a imagem um do outro. É ela que diz o que já aconteceu amanhã.

A própria linha temporal em que se desdobra a experiência sensível do caçador é, portanto, também ela, dupla.

Tomada em seu ângulo dialógico, durante a caçada, a palavra deve permanecer entre si; um explosivo, silenciada para tornar-se silenciadora de toda palavra alheia. Agora nada mais é antecipação, tudo é realização, encontro do um e do outro. Primeiro ela traça, com um só gesto, a linha do animal e o outro da linha-de-combinação dos caçadores. Depois traça o ponto de inflexão onde a caça humana obriga a guerra dos porcos a negar a si mesma.

São esses os aspectos de uma cosmologia perspectivista amazônica a que a caça de porco do mato dá acesso. A estrutura que a noção de ponto de vista permite configurar é, em primeiro lugar, feita de tempo: linhas espaço-temporais ou acontecimentos e seus duplos, e os duplos de seus duplos. Em segundo lugar, ela é uma dinâmica na qual a Palavra virtual do animal é tudo. Ensina ainda que a realidade para o caçador quando ele toma a palavra para falar de si mesmo faz parte de realidades para outrem. Desse modo, o sujeito ao qual os acontecimentos são referenciados não é um centro em torno do qual gira seu próprio mundo. Trata-se antes de um Sujeito disperso no tempo-e-espaço cósmico, duplicado entre a vida sensível e a vida da alma, partido entre Natureza e Sobrenatureza, e complexificado por seu Outro - no caso em pauta, o outro do porco do mato.

Mas isso que você propõe - dir-se-ia — redunda em uma hipótese que, se me permite o jogo de palavras, é a seguinte: a estrutura formal da narrativa mítica, que se confunde, aliás, com a substância da mesma, é a forma estrutural do tempo do caçador. Sendo assim, o tempo histórico do caçador, que você chamou de tempo bilinear múltiplo, poderia ser chamado de tempo mítico. E isso me lembra, retruco eu, o que Joana Overing escreveu recentemente: “Vemos nosso conceito de tempo linear e 
progressivo como um princípio abstrato que reflete a realidade tal como ela realmente é..." (Overing, 1995:132). Eu gostaria que meu conceito também refletisse a realidade dos Juruna tal como ela é. Mas não entenda o que eu não disse, que o tempo bilinear múltiplo seja a única forma temporal que a sua cosmologia traça para eles. Pois, afinal, como saber antecipadamente a configuração que o tucunaré, ou a Palavra dos mortos, traça para os Juruna?

Post scriptum dedicado a Vanessa Lea. Os Juruna desenham em sua pele, nas cuias para servir cauim e em outras superfícies, bem como tramam em suas redes, belos padrões de labirinto. Essa arte gráfica era intrigante para mim pelo decidido silêncio que a cultura juruna mantém no que diz respeito a ela. O homem que olhar demais para a pele de uma mulher assim desenhada, tentando seguir com os olhos os pares de linhas que se infletem e se multiplicam, formando motivos que se repetem um número multiplicado de vezes e cobrem todo o seu corpo, corre o risco de se perder nos caminhos da superfície da realidade. Isso é tudo. O simbolismo que nela procurei, em vão, talvez jamais tenha existido, talvez não possa existir. Quem sabe, essas linhas desenhadas na pele, a cultura sendo ela mesma seu comentário, não são as formas puras das estruturas formadas pelas linhas do tempo. Não posso aqui examinar esse problema. Mas tenho de me pronunciar sobre um ponto de minha análise que permanece inconcluso - ele se torna ainda mais evidente após a aproximação dos desenhos da pele - relativo ao caráter aberto ou fechado da estrutura temporal que descrevi.

Considerando-se que a metafísica da caça situa um sonho no início e outro no fim da história de uma caçada, dados como caça antecipada e prolongamento de caça já realizada na experiência sensível; considerando-se também que essa metafísica coloca o passado e o futuro em uma relação metafórica ou de paralelismo, podemos afirmar que o sonho inicial é paralelo ao sonho final, formando assim a moldura das demais linhas da caça. A história do caçador (afora o fato de ele trazer na pele cicatrizes que lhe permitem recordar antigas aventuras) compõe-se, assim, de inúmeros motivos - muitos dos quais incompletos, por sorte ou azar seu emoldurados por sonhos (seus ou de outrem, factuais ou virtuais), eles mesmos emoldurados pelas compridas linhas da Vida e do Sonho do caçador. 
Tânia Stolze Lima é professora do Departamento de Antropologia da Universidade Federal Fluminense; mestre e doutora pelo Programa de PósGraduação em Antropologia Social (PPGAS) do Museu Nacional/UFRJ. E-mail: goldman@ax.ibase.org.br

\section{Notas}

1 Quero registrar que este artigo é o resultado de um diálogo com Eduardo Viveiros de Castro.

2 Esta seção retoma (com pequenas modificações) um trecho da tese de doutoramento que concluí recentemente (Lima 1995).

3 O narrador parece sugerir que "mel-pênis" é o nome recitado para o "melandorinha", mas não se trata disso; são méis produzidos por duas abelhas diferentes. A propósito, em uma lista de 24 nomes de mel, predomina a associação de particularidades da abelha com particularidades de animais. Por exemplo, o "meljacu" é produzido por uma abelha cuja cabeça é dita lembrar a do jacu; o "melsaúva" é produzido por uma que tem cheiro de saúva. Há casos anômalos: o "melcoatá" é produzido por uma abelha identificada como "aquela cujas patas são parecidas às do maribondo". Há casos em que o nome é construído por associação com o orifício da colméia — é este o caso do "mel-vagina", produzido por abelhas de distintas espécies.

4 Para a distinção entre afinidade potencial e afinidade virtual, ver Viveiros de Castro (1993:167-168). Registre-se também que o risco do abuso de linguagem transcende o domínio da caça dos porcos e assume o caráter de regra geral da caça. Isto sucedeu a um finado que, de tão exaltado um fim de tarde em que se combinava uma caçada de anta, exclamou para os companheiros: "Pois eu vou enfiar meu braço no cu da anta e vou arrancar o coração dela!". No dia seguinte, foi o que ele tentou; porém, mal sua mão atravessou o ânus do animal, este contraiu o esfíncter e saiu em disparada. O infeliz estava quase completamente mudado em anta quando o reencontraram em uma caçada na qual os caçadores flecharam um casal de antas. Antes de morrer, o macho lhes disse quem era ele. Os caçadores deixaram-no apodrecer na floresta e comeram a fêmea, em cujo ventre encontraram um feto humano.

5 Aliás, eu não poderia passar a outro ponto sem mencionar a retomada do termo animismo que Descola (1992) propôs recentemente, visando à criação de uma tipologia das formas de relação com a alteridade e com a natureza. O animismo, segundo afirma, representaria um tipo simétrico e inverso ao totemismo. É verdade que sua hipótese de trabalho desperta questões teóricas específicas 
para a etnologia amazônica, bem como questões metodológicas gerais, bastante interessantes. Mas eu não poderia discuti-la aqui sem me afastar de meu objetivo. Quero lembrar que as reflexões que apresento neste artigo não se articulam senão muito indiretamente com as hipóteses sugeridas por Descola, e, quando falo em animismo, não me refiro ao conceito que ele assim batizou.

6 Em meus materiais, a noção de ponto de vista é marcada de uma forma muito simples: aos pronomes pessoais objetivos, acrescenta-se uma partícula que significa "para". Existe, porém, uma diferença capital entre a noção propriamente dita e sua expressão lingüística: esta tem um uso muito mais geral. Assim, uma frase como "isso é anta para mim" quer dizer, simplesmente, que o sujeito dá a certa carne o mesmo uso que outrem dá à anta (Lima 1995:19). Ou seja, a mesma expressão lingüística também é usada para se fazer analogias.

7 Prado Jr. (1994) para o relativismo no pensamento filosófico; Latour (1994) para o relativismo culturalista e o lévi-straussiano.

8 "O discurso xamanístico é um jogo teatral de citações de citações, reflexos de reflexos, ecos de ecos — interminável polifonia onde quem fala é sempre o outro, fala do que fala o Outro. A palavra Alheia só pode ser apreendida em seus reflexos [...]" (Viveiros de Castro 1986:570).

9 Assinale-se a grande variedade das formas de expressão da noção de ponto de vista nas diferentes culturas amazônicas e provavelmente no interior de cada uma. Os Matsiguenga, por exemplo, desenvolvem um aspecto do qual não conheço exemplo na etnografia Juruna: do ponto de vista da lua e outras categorias os humanos não aparecem como tais, mas como antas ou caititus (Baer 1994:224). Não pude ainda fazer um inventário exaustivo para os Juruna, mas adianto os seguintes padrões. (1) Como esquema geral: são dados dois sujeitos e duas categorias; estas são distintas de acordo com um dos sujeitos e indiferenciadas de acordo com o outro. A distinção é uma ótica geralmente assumida pelos humanos e sucede que eles são traídos por esse mesmo dom para a diferenciação. (2) Uma categoria (empírica ou não) relacionada com uma região cósmica determinada transforma-se em outra categoria a fim de transitar em terra alheia - a transformação sendo uma potência da própria categoria, a qual sustenta o ponto de vista que era o seu antes da transformação. (3) Uma categoria empírica, destituída de ponto de vista, sofre uma alteração por atravessar domínios cósmicos. (4) Animais tomam a parte pelo todo. (5) No sonho, o ponto de vista alheio determina o sentido de imagens oníricas. (Quando o olhar dos porcos se deita sobre uma amiga e eu, as águas do rio onde tomávamos banho se transformam em lama, ao nosso olhar, e em mandioca pubando para o cauim, ao olhar dos porcos.) Veja-se, ainda, que o problema remete para a (aparentemente) dupla questão da metamorfose e do devir, e para a heterogeneidade do espaço. Não poderei abordar aqui nem uma nem outra.

${ }^{10}$ Isso deve ser matizado. Os urubus, por exemplo, têm certos itens culturais apenas seus, mas os Juruna, nos tempos remotos, roubaram-nos. Um diadema de 
palha bastante típico da identidade cultural desse grupo (segundo ressaltam os próprios Juruna) pertence aos urubus. Também entre os Makuna, os urubus, à diferença dos outros animais, apresentam certa diversidade cultural: partilham a louça de cozinha com os Brancos (Århem 1993:116).

11 Uso o termo paralelismo em sua acepção literária, e de acordo com a teoria jakobsoniana da poética (Jakobson 1963; 1977). Esse é o princípio que predomina nas narrativas míticas indígenas e os Juruna empregam-no eventualmente na prosa cotidiana. Ver seu aparecimento nesse comentário sobre a refeição das almas no festival dos mortos ('i'ãnay):

"Os 'i'ãnay comem a comida, mas não comem, não.

Eles dizem que as panelas estão vazias, é mentira deles!

Para si próprios a comida acabou, para nós próprios a comida está lá.

Eles só comem a alma do peixe, e, comendo, a alma acaba para eles.

'O peixe acabou! As panelas estão vazias!

Vocês podem comer também... se sobrou... vocês podem comer', dizem eles" (Lima 1995:260).

12 Registre-se que apenas a morte pode efetuar essa conjugação da alma humana com o sujeito. Como, porém, o perspectivismo também atua na sociedade dos mortos que habitam os rochedos, assim como em sua relação com os vivos e as almas dos mortos canibais que habitam uma aldeia celeste, o morto também organiza sua experiência em termos de corpo/alma, ou sujeito/duplo.

13 Aqui também, o tema da alma animal diverge do tema da alma humana, que, na morte, apresenta uma incompatibilidade fundamental com o cadáver.

\section{Referências bibliográficas}

ÅRHEM, Kaj. 1993. "Ecosofía Makuna". In: F. Correa (org.), La Selva Humanizada: Ecología Alternativa en el Trópico Húmedo Colombiano. Bogotá: Instituto Colombiano de Antropología/Fondo FEN Colombia/Fondo Editorial CEREC. pp. 109-126.

BAER, Gerhard. 1994. Cosmología y Shamanismo de los Matsiguenga. Quito: Ediciones Abya-Yala.

CLASTRES, Pierre. 1974a. "De l'Un sans le Multiple". In: La Société contre l'État. Paris: Minuit. pp. 146-151. _.1974b. Le Grand Parler. Paris: Seuil.

DELEUZE, Gilles. 1991. A Dobra: Leibniz e o Barroco. Campinas: Papirus. e GUATTARI, Félix. 1995. Mil Platôs. Capitalismo e Esquizofrenia (vol. 2). Rio de Janeiro: Editora 34.

DESCOLA, Philippe. 1992. "Societies of Nature and the Nature of Society". In: A. Kuper (org.), Conceptualizing Society. London/New York: Routledge. pp. 107-126.

GEERTZ, Clifford. 1983. "'From the 
Native's Point of View': On the Nature of Anthropological Understanding". In: Local Knowledge. New York: Basic Books. pp. 55-70.

HOWELL, Signe. 1984. Society and Cosmos. Chewong of Peninsular Malaysia. Oxford: Oxford University Press.

JAKOBSON, Roman. 1963. "Linguistique et Poétique". In: Essais de Linguistique Général 1. Les Fondations du Langage. Paris: Minuit. pp. 209-248.

_ . 1977. "Qu'est-ce que la Poésie". In: Huit Questions de Poétique. Paris: Seuil. pp. 31-49.

LATOUR, Bruno. 1994. Jamais Fomos Modernos. Rio de Janeiro: Editora 34.

LAWRENCE, D. H. 1986. Mornings in Mexico. London: Penguin Books.

LÉVI-STRAUSS, Claude. 1976a. "Raça e História". In: Antropologia Estrutural Dois. Rio de Janeiro: Tempo Brasileiro. pp. 328-366. .1976b. O Pensamento Selvagem. São Paulo: Cia. Editora Nacional.

LÉVINAS, Emmanuel. 1957. "Lévy-Bruhl et la Philosophie Contemporaine". Revue Philosophique de la France et de l'Étranger, 4:556-569.

LÉVY-BRUHL, Lucien. 1931. Le Surnaturel et la Nature dans la Mentalité Primitive. Paris: Félix Alcan.

LIMA, Tânia Stolze. 1986. A Vida Social entre os Yudjá: Elementos de sua Ética Alimentar. Dissertação de Mestrado. PPGAS/Museu Nacional/UFRJ. .1995. A Parte do Cauim. Etnografia Juruna. Tese de Doutoramento. PPGAS/Museu Nacional/UFRJ.

OVERING, Joanna. 1995. "O Mito como História: Um Problema de Tempo, Realidade e Outras Questões". Mana, 1(1):107-140 .

PRADO JR., Bento. 1994. "O Relativismo como Contraponto". In: A. Cícero e W. Salomão (orgs.), O Relativismo enquanto Visão do Mundo. Rio de
Janeiro: Francisco Alves. pp. 71-94. TURNER, Terence. 1991. “'We Are Parrots, Twins Are Birds': Play of Tropes as Operational Structure". In: J. W. Fernandez (org.), Beyond Metaphor. The Theory of Tropes in Anthropology. Stanford: Stanford University Press. pp. 121-158.

VIVEIROS DE CASTRO, Eduardo. 1986. Araweté, Os Deuses Canibais. Rio de Janeiro: Jorge Zahar/Anpocs. .1993. "Alguns Aspectos da Afinidade no Dravidianato Amazônico". In: E. Viveiros de Castro e M. Carneiro da Cunha (orgs.), Amazônia: Etnologia e História Indígena. São Paulo: NHII/USP-FAPESP. pp. 149-210. . 1996a. "Le Meurtrier et son Double chez les Araweté (Brésil): Un Exemple de Fusion Rituelle". In: M. Cartry e M. Detienne (orgs.), Destins de Meurtriers. Paris: CNRS [Systèmes de Pensée en Afrique Noire, 14]. pp. 77-104.

. 1996b. "Os Pronomes Cosmológicos e o Perspectivismo Ameríndio". Mana, 2(2):115-144. 


\section{Resumo}

A partir da caça de porco do mato, este artigo é um ensaio etnográfico sobre uma noção indígena de ponto de vista, aplicada ao campo das relações entre o humano e o animal, na cosmologia de um povo Tupi, os Juruna. Além de revelar a complexidade particular dessas relações, a noção de ponto de vista permite mostrar como a noção de duplo é irredutível à noção de alma, como "natureza" e "sobrenatureza" são efeitos de perspectivas, e como, finalmente, a caça se insere em uma estrutura espaço-temporal bilinear múltipla, evocadora dos "labirintos" que os Juruna desenham na pele.

\section{Abstract}

This article takes the wild boar hunt as the basis for an ethnographic essay on an indigenous notion of point of view, applied to the field of relations between humans and animals in the cosmology of a Tupi people, the Juruna. In addition to revealing the particular complexity of these relations, the concept of point of view shows how the notion of double is irreducible to that of soul, like "nature" and "supernature" are effects of perspectives, and finally how the hunt is included in a multiple bilinear spatial/temporal structure, evoking the "labyrinths" that the Juruna paint on their skin. 